\title{
Effects of telmisartan and losartan on cardiovascular protection in Japanese hypertensive patients
}

\author{
Hiroshi Hasegawa ${ }^{1}$, Hiroyuki Takano ${ }^{1}$, Hiroya Narumi ${ }^{1}$, Masashi Ohtsuka ${ }^{2}$, Tadahiko Mizuguchi ${ }^{3}$, \\ Takao Namiki ${ }^{4}$, Yoshio Kobayashi ${ }^{1}$ and Issei Komuro ${ }^{5}$
}

The Telmisartan and Losartan Cardiac Evaluation Trial, a multicenter, prospective, randomized, open-labeled, blinded-endpoint trial, was designed to compare the effects of two angiotensin II receptor blockers (ARBs), telmisartan and losartan, on cardiovascular protection in Japanese patients with mild to moderate essential hypertension. We compared the effects of telmisartan and losartan on left ventricular (LV) hypertrophy, cardiac function, atherosclerosis of carotid arteries and surrogate markers related to the actions of peroxisome proliferator-activated receptor- $\gamma$. A total of 58 patients were enrolled in the present trial and the follow-up period was 1 year. There were no significant differences in blood pressure (BP) levels between the telmisartan group and the losartan group throughout the trial. The percentage of the patients treated with ARB monotherapy was significantly higher in the telmisartan group compared with the losartan group. In addition, the progression of intima-media thickness of common carotid artery was significantly inhibited in the telmisartan group compared with the losartan group. Neither group experienced significant changes in cardiac function and LV mass index. There were no differences between the groups with respect to changes in surrogate markers such as serum adiponectin, creatinine, homeostasis model assessment index, plasminogen activator inhibitor-1 and high sensitivity C-reactive protein. Although BP levels were equal and well controlled in both groups, telmisartan showed more protective vascular effects than losartan.

Hypertension Research (2011) 34, 1179-1184; doi:10.1038/hr.2011.114; published online 28 July 2011

Keywords: angiotensin II receptor blocker; clinical trial; intima-media thickness; telmisartan

\section{INTRODUCTION}

Hypertension is the most common disease and cardiovascular disease is the main cause of death in hypertensive patients in Japan. ${ }^{1}$ Angiotensin II receptor blockers (ARBs) and angiotensin-converting enzyme (ACE) inhibitors, which inhibit the renin-angiotensin system, are known to have cardiovascular protective effects that extend beyond reduction of blood pressure (BP). Adaptive responses to hemodynamic and non-hemodynamic stimuli such as cardiovascular remodeling, left ventricular (LV) hypertrophy and atherosclerosis are frequently found in hypertensive patients. As excessive remodeling increases the risk of cardiovascular morbidity and mortality, the intensive management of hypertension is critical for the prevention of cardiovascular events in hypertensive patients. Many randomized clinical trials have shown the beneficial effects of ARBs on cardiovascular morbidity and mortality in patients with hypertension, heart failure, stroke or end-stage renal disease. ${ }^{2-7}$

Metabolic syndrome (MetS), a cluster of certain clinical conditions including visceral obesity, hyperglycemia, dyslipidemia and hypertension, represents a significant risk factor for developing cardiovascular disease. ${ }^{8-10}$ Visceral fat-induced insulin resistance has been suggested as an underlying pathogenic mechanism for MetS. ${ }^{11}$ MetS is also known to be associated with disorders of peroxisome proliferatoractivated receptor- $\gamma(\operatorname{PPAR} \gamma),{ }^{12}$ an intracellular hormone receptor with a significant role in carbohydrate and lipid metabolism. ${ }^{13}$ PPAR $\gamma$ agonists improve insulin resistance in patients with type 2 diabetes mellitus (DM). ${ }^{14,15}$

Telmisartan bears a structural resemblance to $\operatorname{PPAR} \gamma$ agonist pioglitazone, which suggests that telmisartan may activate PPAR $\gamma$. In vitro studies have shown that telmisartan acts as a partial agonist of PPAR $\gamma$ and modulates the expressions of PPAR $\gamma$ target genes involved in carbohydrate and lipid metabolism. ${ }^{16}$ One report suggests that telmisartan, in contrast to some other ARBs, may exert additional effects through activation of PPAR $\gamma .{ }^{17}$ Telmisartan induces adiponectin expression via PPAR $\gamma$ activation ${ }^{18}$ and proliferates human endothelial progenitor cells via a PPAR $\gamma$-dependent PI3K/Akt signaling pathway. ${ }^{19}$ Given that telmisartan causes angiotensin II blockade and PPAR $\gamma$ activation, it might be expected to have clinical cardiovascular protective effects beyond the ARB class effects. The Ongoing

\footnotetext{
${ }^{1}$ Department of Cardiovascular Science and Medicine, Chiba University Graduate School of Medicine, Chiba, Japan; ${ }^{2}$ Department of Cardiovascular Medicine, Seirei Yokohama Hospital, Yokohama, Japan; ${ }^{3}$ Department of Cardiovascular Medicine, Chiba Social Insurance Hospital, Chiba, Japan; ${ }^{4}$ Department of Frontier Japanese-Oriental 'Kampo' medicine, Chiba University Graduate School of Medicine, Chiba, Japan and ${ }^{5}$ Department of Cardiovascular Medicine, Osaka University Graduate School of Medicine, Osaka, Japan

Correspondence: Dr H Takano, Department of Cardiovascular Science and Medicine, Chiba University Graduate School of Medicine, 1-8-1 Inohana, Chuo-ku, Chiba 260-8670, Japan. 
Telmisartan Alone and in Combination with Ramipril Global Endpoint Trial reported that telmisartan was as effective as and better tolerated than ramipril, the most powerful ACE inhibitor, in terms of the primary cardiovascular outcome during a 56-month follow-up. ${ }^{20}$ Therefore, it is important to investigate the differences in the effects of ARBs to determine the optimal treatment in hypertensive patients. Because clinical responses to therapeutic agents and event rates of cardiovascular disease differ between Asian and Western populations, the data from the trials performed in other countries are not necessarily applicable to Japanese patients.

Therefore, it would be interesting to compare the effects of telmisartan to other ARBs in Japanese hypertensive patients. The Telmisartan and Losartan Cardiac Evaluation Trial (TALENT), reported here, was designed to investigate whether telmisartan has superior cardiovascular protective effects compared with losartan in Japanese patients with mild to moderate hypertension.

\section{METHODS}

\section{Study population}

The inclusion criteria were an age of 30-70 years and a diagnosis of mild to moderate hypertension, defined as systolic BP (SBP) $\geqslant 140 \mathrm{~mm} \mathrm{Hg}$ and/or diastolic BP (DBP) $\geqslant 90 \mathrm{~mm} \mathrm{Hg}$, measured in a seated position at a clinic. The exclusion criteria were as follows: secondary hypertension; a history of heart failure; DM treated with pioglitazone; a history of acute myocardial infarction (MI), percutaneous coronary intervention or coronary artery bypass graft within 6 months before the randomization; a history of stroke within 3 months before the randomization; serious renal dysfunction (serum creatinine $\geqslant 3 \mathrm{mg} \mathrm{dl}^{-1}$ ) and malignant disease. We enrolled 58 patients with mild to moderate hypertension between January 2006 and September 2008. TALENT ended in December 2009.

\section{Study design}

TALENT was a multicenter, prospective, randomized, open-labeled, blindedendpoint (PROBE) design. The trial sought to compare two antihypertensive treatment strategies at nine medical facilities in Japan. The ethics committee at Chiba University Graduate School of Medicine approved the protocol, which adhered to the principles of the Helsinki Declaration. Participants were randomly assigned to either the telmisartan group or the losartan group by the envelope method after informed consent had been obtained. Data entry and data collection were performed at Chiba University, which served as the trial's center. Each patient's BP was measured at a clinic, using a validated mercury sphygmomanometer with the individual in a seated position. The mean of three measurements was calculated and recorded. We aimed to control BP to $<140 /$ $90 \mathrm{~mm} \mathrm{Hg}$ in both treatment groups. The first dose of telmisartan or losartan was 40 or $50 \mathrm{mg}$ per day, respectively. If the patient's BP did not reach the BP target, the doses were increased to 80 or $100 \mathrm{mg}$ per day, respectively. Calcium channel blockers and other antihypertensive drugs could then be added if necessary. If the patients were already receiving antihypertensive treatment before enrollment, their medication was changed to either $40 \mathrm{mg}$ per day telmisartan or $50 \mathrm{mg}$ per day losartan without a run-in period. This trial was registered at http://www.umin.ac.jp/ctr/index.htm (identifier C000000331).

\section{Outcome measurements}

The primary endpoint was a composite of the effects on LV mass index (LVMI), cardiac function (LV ejection fraction, LV inflow E/A, deceleration time, brain natriuretic peptide) and intima-media thickness (IMT) of common carotid artery. The secondary endpoints were the effects on PPAR $\gamma$-related actions. After enrollment, routine laboratory tests, including serum adiponectin, homeostasis model assessment (HOMA) index, plasminogen activator inhibitor-1, high sensitivity C-reactive protein, total cholesterol, insulin and HbAlc, were performed every 6 months. Echocardiography and ultrasonography were performed at baseline and after 12 months. LV mass was measured using M-mode guided echocardiography, according to the formula introduced by Devereux et al. ${ }^{21}: 0.80 \times\{1.04 \times[($ septal thickness $+\mathrm{LV}$ internal diameter $\times$ posterior wall thickness $\left.\left.)^{3}-(\text { LV internal diameter })^{3}\right]\right\}+0.6$ g; LVMI was calculated with a body surface area correction. A standardized scanning protocol common to all recruiting centers was used to measure IMT. In each center, certified trained physicians or technicians performed high-resolution B-mode ultrasounds of extracranial carotid arteries bilaterally, according to the previously described scanning protocol. ${ }^{22}$

\section{Statistical analysis}

Quantitative data are expressed as mean \pm s.d. The differences in the baseline parameters were analyzed with $\chi^{2}$-tests. Paired samples were compared by a paired comparison's $t$-test. To analyze changes in BP, we used repeated measurement two-way analysis of variance. $P$-values were computed by the Bonferroni test for inter-group comparisons at the end of the trial. To identify independent relationships between several factors and carotid IMT progression, step-wise multivariate regression with forward selection was used. Only variables with $P<0.05$ in the univariate analysis were included in the multivariate analysis. All the statistical tests were two-sided, and $\alpha$-level $<0.05$ was considered to be statistically significant. The statistical software package SPSS version 18.0 (SPSS, Chicago, IL, USA) was used for all analyses.

\section{RESULTS}

\section{Baseline characteristics}

A total of 58 patients were enrolled. Of these patients, 30 were assigned to the telmisartan group (mean age: $59.1 \pm 10.3$ years, female: $31.0 \%$ ) and 28 were assigned to the losartan group (mean age: $56.4 \pm 10.1$ years, female: $32.1 \%)$. Only one patient (1.7\%) was lost to follow-up, an individual in the telmisartan group. Table 1 shows the patients' baseline characteristics. There were no significant differences between the two groups in the baseline characteristics such as age, gender, body mass index, presence or absence of DM, dyslipidemia, cardiovascular disease, LV hypertrophy, antihypertensive treatment before enrollment and the other clinical parameters. No patients were taking anti-platelet drugs. Table 2 shows the biochemical and echocardiographic parameters of the two groups at baseline. There were no significant baseline differences in these parameters between the two groups.

\section{Table 1 Clinical characteristics of patients at baseline}

\begin{tabular}{lccc}
\hline & $\begin{array}{c}\text { Telmisartan group } \\
(\mathrm{n}=29)\end{array}$ & $\begin{array}{c}\text { Losartan group } \\
(\mathrm{n}=28)\end{array}$ & P-value \\
& $59.1 \pm 10.3$ & $56.4 \pm 10.1$ & 0.325 \\
\hline Age (years) & $9(31.0 \%)$ & $9(32.1 \%)$ & 0.646 \\
Female & $25.7 \pm 49$ & $25.9 \pm 4.8$ & 0.868 \\
BMI (kg m $\left.{ }^{-2}\right)$ & $162.6 \pm 8.5$ & $160.7 \pm 8.0$ & 0.391 \\
Height $(\mathrm{cm})$ & $67.9 \pm 12.5$ & $67.1 \pm 13.8$ & 0.836 \\
Weight $(\mathrm{kg})$ & $152.1 \pm 16.5$ & $150.6 \pm 10.6$ & 0.686 \\
SBP (mm Hg) & $90.0 \pm 13.3$ & $92.1 \pm 12.3$ & 0.534 \\
DBP (mm Hg) & $68.5 \pm 10.6$ & $71.3 \pm 11.3$ & 0.381 \\
Pulse rate (beats per min) & $2(6.7 \%)$ & $4(14.3 \%)$ & 0.285 \\
Diabetes mellitus & $3(10.0 \%)$ & $2(7.1 \%)$ & 0.423 \\
Dyslipidemia & $2(6.7 \%)$ & $2(7.1 \%)$ & 0.705 \\
Cardiovascular disease & $8(26.7 \%)$ & $8(28.6 \%)$ & 0.850 \\
Left ventricular hypertrophy & $11(27.9 \%)$ & $9(22.1 \%)$ & 0.766 \\
Antihypertensive treatment & &
\end{tabular}

before enrollment

$\begin{array}{lccc}\text { Medication at baseline } & & & \\ \text { Calcium channel blockers } & 10(34.4 \%) & 8(28.6 \%) & 0.423 \\ \beta \text {-blockers } & 1(3.3 \%) & 0(0 \%) & 0.287 \\ \text { ARBs } & 0(0 \%) & 1(3.6 \%) & 0.285\end{array}$

Abbreviations: ARBs, angiotensin II receptor blockers; BMI, body mass index; DBP, diastolic blood pressure; SBP, systolic blood pressure.

Data are expressed as mean \pm s.d. or number and percentage. 
Table 2 Biochemical and echocardiographic parameters at baseline

\begin{tabular}{|c|c|c|c|}
\hline & $\begin{array}{l}\text { Telmisartan group } \\
\qquad(\mathrm{n}=29)\end{array}$ & $\begin{array}{l}\text { Losartan group } \\
\qquad(\mathrm{n}=28)\end{array}$ & P-value \\
\hline Total cholesterol (mg dl-1) & $205.8 \pm 32.5$ & $202.4 \pm 30.1$ & 0.682 \\
\hline Triglyceride $\left(\mathrm{mg} \mathrm{dl}^{-1}\right)$ & $145.0 \pm 92.6$ & $163.0 \pm 93.8$ & 0.478 \\
\hline HDL cholesterol (mg dl $\left.{ }^{-1}\right)$ & $64.1 \pm 22.6$ & $57.7 \pm 14.8$ & 0.229 \\
\hline LDL cholesterol $\left(\mathrm{mg} \mathrm{dl}^{-1}\right)$ & $120.4 \pm 36.8$ & $116.3 \pm 28.4$ & 0.652 \\
\hline BUN (mg dl-1) & $13.7 \pm 3.7$ & $13.6 \pm 3.7$ & 0.900 \\
\hline Uric acid $\left(\mathrm{mg} \mathrm{dl} l^{-1}\right)$ & $5.6 \pm 1.2$ & $5.7 \pm 1.4$ & 0.721 \\
\hline Serum creatinine $\left(\mathrm{mg} \mathrm{dl}^{-1}\right)$ & $0.8 \pm 0.2$ & $0.7 \pm 0.2$ & 0.332 \\
\hline $\mathrm{Na}\left(\mathrm{mEq} \mathrm{I}^{-1}\right)$ & $141.6 \pm 2.0$ & $141.3 \pm 1.8$ & 0.548 \\
\hline $\mathrm{K}\left(\mathrm{mEq} \mathrm{I}^{-1}\right)$ & $4.3 \pm 0.4$ & $4.2 \pm 0.5$ & 0.827 \\
\hline $\mathrm{Cl}\left(\mathrm{mEqI}^{-1}\right)$ & $104.8 \pm 2.6$ & $105.6 \pm 6.0$ & 0.555 \\
\hline Fasting blood sugar ( $\mathrm{mg} \mathrm{dl}^{-1}$ ) & $107.0 \pm 19.0$ & $112.6 \pm 21.6$ & 0.333 \\
\hline HbAlc (\%) & $5.1 \pm 1.0$ & $5.5 \pm 1.0$ & 0.087 \\
\hline Adiponectin $\left(\mu \mathrm{g} \mathrm{ml}^{-1}\right)$ & $5.7 \pm 3.4$ & $5.1 \pm 3.2$ & 0.519 \\
\hline $\mathrm{hs}-\mathrm{CRP}\left(\mathrm{mgl}^{-1}\right)$ & $1.5 \pm 2.3$ & $1.0 \pm 1.3$ & 0.322 \\
\hline PAl-1 (ng ml-1) & $27.4 \pm 15.5$ & $27.8 \pm 10.4$ & 0.913 \\
\hline Insulin $\left(\mu \cup \mathrm{ml}^{-1}\right)$ & $9.6 \pm 15.5$ & $9.0 \pm 7.0$ & 0.750 \\
\hline HOMA index & $2.6 \pm 1.4$ & $2.4 \pm 1.8$ & 0.668 \\
\hline BNP $\left(p g \mathrm{ml}^{-1}\right)$ & $42.5 \pm 47.9$ & $22.0 \pm 27.8$ & 0.061 \\
\hline LVDd (mm) & $48.4 \pm 4.5$ & $45.8 \pm 3.7$ & 0.024 \\
\hline LVDs (mm) & $29.9 \pm 4.5$ & $28.8 \pm 3.9$ & 0.341 \\
\hline IVSTd (mm) & $10.1 \pm 1.9$ & $10.2 \pm 1.9$ & 0.893 \\
\hline PWTd (mm) & $9.9 \pm 1.4$ & $10.4 \pm 1.6$ & 0.283 \\
\hline LV mass index $\left(\mathrm{g} \mathrm{m}^{-2}\right)$ & $102.1 \pm 15.8$ & $98.3 \pm 20.0$ & 0.457 \\
\hline LVEF (\%) & $67.7 \pm 7.8$ & $66.1 \pm 7.6$ & 0.427 \\
\hline$E / A$ & $0.9 \pm 0.3$ & $0.9 \pm 0.3$ & 0.954 \\
\hline DcT (ms) & $201.8 \pm 32.4$ & $188.5 \pm 50.4$ & 0.299 \\
\hline
\end{tabular}

Abbreviations: BNP, brain natriuretic peptide; DcT, deceleration time; HbAlc, hemoglobin Alc; HDL, high-density lipoprotein; HOMA index, homeostasis model assessment index; hs-CRP, high sensitivity-C-reactive protein; IVSTd, interventricular septum thickness in diastole; LDL lowdensity lipoprotein; LVDd, left ventricular internal dimension in diastole; LVDs, left ventricular diameter at end systole; LVEF, left ventricular ejection fraction; PAI-1, plasminogen activator inhibitor-1; PWTd, posterior left ventricular wall thickness in diastole.

Data are expressed as mean \pm s.d.

Table 3 Concomitant medications

\begin{tabular}{lccc}
\hline & $\begin{array}{c}\text { Telmisartan group } \\
\mathrm{n}=29(\%)\end{array}$ & $\begin{array}{c}\text { Losartan group } \\
\mathrm{n}=28(\%)\end{array}$ & P-value \\
\hline Monotherapy & $19(63.3)$ & $12(42.9)$ & 0.040 \\
Calcium channel blockers & $10(34.4)$ & $15(53.6)$ & 0.192 \\
$\beta$-blockers & $1(3.3)$ & $1(3.6)$ & 0.705 \\
$\alpha$-blockers & $0(0)$ & $1(3.6)$ & 0.285 \\
Diuretics & $0(0)$ & $1(3.6)$ & 0.285 \\
\hline
\end{tabular}

Data are expressed as number and percentage.

Follow-up and adherence to the treatment

At the end of the trial, the percentage of patients who received only telmisartan or losartan (monotherapy) was significantly higher in the telmisartan group than in the losartan group (telmisartan group 63.3\%, losartan group $42.9 \%, P=0.040$ ) (Table 3). In both groups, the additional treatments were mainly calcium channel blockers. The losartan group had a slightly higher average of antihypertensive agents taken during the study (telmisartan group $1.52 \pm 0.81$; losartan group $1.75 \pm 0.84)$. No adverse events were reported in either group.

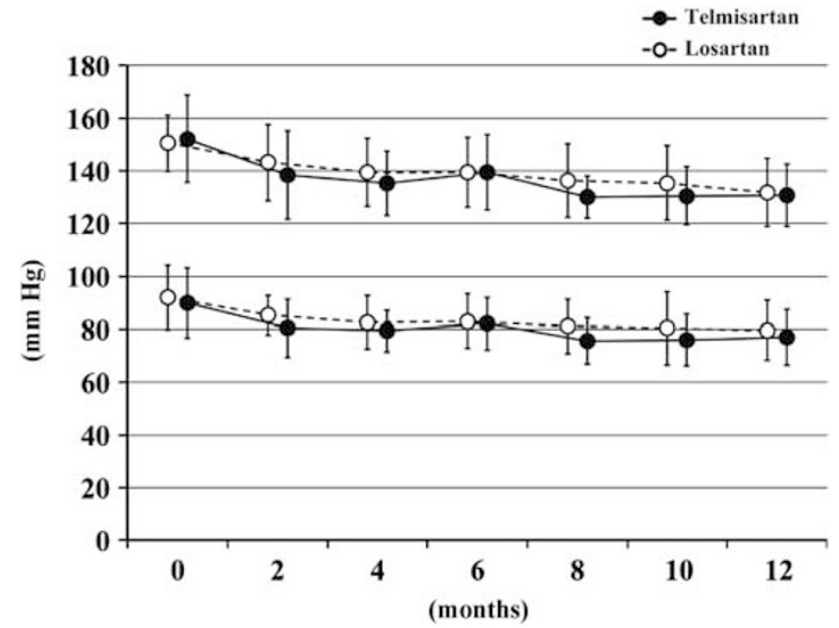

Figure 1 Changes in systolic blood pressure and diastolic blood pressure. Data are expressed as the mean \pm s.d.

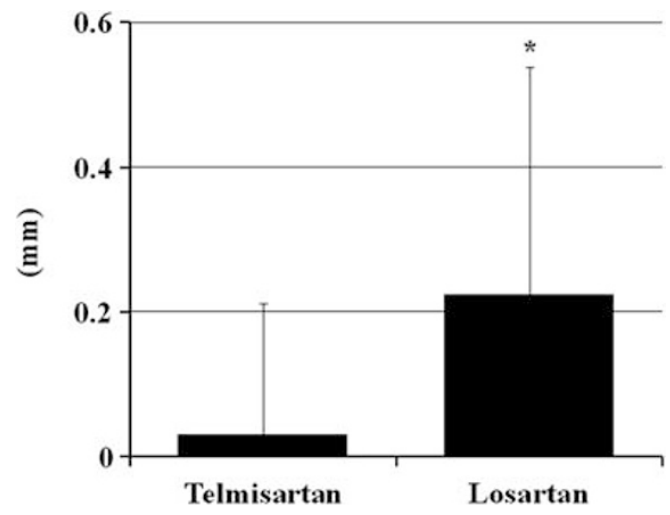

Figure 2 The changes in intima-media thickness of the common carotid artery over 1 year. Data are expressed as the mean \pm s.d. ${ }^{*} P<0.05$.

BP

Figure 1 shows that BP was substantially reduced in both treatment groups. The mean BP in the telmisartan group was $152 \pm 17 /$ $90 \pm 13 \mathrm{~mm} \mathrm{Hg}$ at baseline and $131 \pm 12 / 77 \pm 10 \mathrm{~mm} \mathrm{Hg}$ after 1 year. The mean BP in the losartan group was $150 \pm 10 / 92 \pm 12 \mathrm{~mm} \mathrm{Hg}$ at baseline and $132 \pm 13 / 80 \pm 11 \mathrm{~mm} \mathrm{Hg}$ after 1 year. Both SBP and DBP were well controlled in both groups, and there were no significant differences in BP levels between the two groups throughout the trial. The target BP was achieved in $23(77 \%)$ patients in the telmisartan group and $20(71 \%)$ patients in the losartan group throughout the trial.

\section{Outcomes}

The IMT values of the common carotid artery at baseline and after 1 year were $0.94 \pm 0(36 \mathrm{~mm}$ and $0.95 \pm 0.38 \mathrm{~mm}$ in the telmisartan group and $0.86 \pm 0.23 \mathrm{~mm}$ and $1.06 \pm 0.44 \mathrm{~mm}$ in the losartan group, respectively). Although progressions of IMT were found in both groups, the change was significantly smaller in the telmisartan group than in the losartan group $(P=0.013)$ (Figure 2). Multivariate stepwise linear regression analysis of the change of IMT for variables including HbAlc, SBP, DBP, total cholesterol, triglyceride, brain natriuretic peptide, adiponectin, fasting blood sugar and HOMA 
Table 4 Biochemical and echocardiographic parameters after 1 year

\begin{tabular}{|c|c|c|c|}
\hline & $\begin{array}{l}\text { Telmisartan group } \\
\qquad(\mathrm{n}=29)\end{array}$ & $\begin{array}{l}\text { Losartan group } \\
\qquad(\mathrm{n}=28)\end{array}$ & P-value \\
\hline Total cholesterol $\left(\mathrm{mg} \mathrm{dl}^{-1}\right)$ & $200.0 \pm 33.2$ & $206.4 \pm 32.4$ & 0.715 \\
\hline Triglyceride $\left(\mathrm{mg} \mathrm{dl}^{-1}\right)$ & $172.9 \pm 147.0$ & $184.6 \pm 108.5$ & 0.741 \\
\hline HDL cholesterol $\left(\mathrm{mg} \mathrm{dl}^{-1}\right)$ & $58.6 \pm 15.2$ & $57.2 \pm 13.6$ & 0.714 \\
\hline LDL cholesterol (mg dl-1) & $113.4 \pm 26.7$ & $114.3 \pm 30.7$ & 0.911 \\
\hline $\mathrm{BUN}\left(\mathrm{mg} \mathrm{dl^{-1 }}\right)$ & $14.2 \pm 3.5$ & $14.3 \pm 3.4$ & 0.890 \\
\hline Uric acid $\left(\mathrm{mg} \mathrm{dl}^{-1}\right)$ & $5.7 \pm 1.3$ & $5.4 \pm 1.5$ & 0.550 \\
\hline Serum creatinine $\left(\mathrm{mg} \mathrm{dl}^{-1}\right)$ & $0.8 \pm 0.2$ & $0.7 \pm 0.2$ & 0.330 \\
\hline $\mathrm{Na}\left(\mathrm{mEq} \mathrm{I}^{-1}\right)$ & $142.1 \pm 1.9$ & $141.1 \pm 2.0$ & 0.060 \\
\hline $\mathrm{K}\left(\mathrm{mEq} \mathrm{I}^{-1}\right)$ & $4.3 \pm 0.3$ & $4.2 \pm 0.4$ & 0.360 \\
\hline $\mathrm{Cl}\left(\mathrm{mEql}^{-1}\right)$ & $104.9 \pm 2.8$ & $104.2 \pm 2.8$ & 0.375 \\
\hline Fasting blood sugar $\left(\mathrm{mg} \mathrm{dl}^{-1}\right)$ & $107.1 \pm 19.6$ & $115.2 \pm 33.9$ & 0.302 \\
\hline $\mathrm{HbAlc}(\%)$ & $5.4 \pm 0.6$ & $5.7 \pm 1.1$ & 0.285 \\
\hline Adiponectin $\left(\mu \mathrm{g} \mathrm{ml}^{-1}\right)$ & $5.4 \pm 3.2$ & $5.1 \pm 3.0$ & 0.813 \\
\hline hs-CRP (mgl-1) & $1.4 \pm 2.2$ & $1.2 \pm 1.4$ & 0.723 \\
\hline PAl-1 (ng ml-1) & $31.0 \pm 21.0$ & $31.5 \pm 17.4$ & 0.934 \\
\hline Insulin $\left(\mu \cup \mathrm{ml}^{-1}\right)$ & $13.6 \pm 11.1$ & $14.6 \pm 14.4$ & 0.825 \\
\hline HOMA index & $3.9 \pm 3.7$ & $4.2 \pm 5.0$ & 0.844 \\
\hline BNP $\left(\mathrm{pg} \mathrm{ml}^{-1}\right)$ & $24.0 \pm 27.4$ & $18.2 \pm 20.6$ & 0.407 \\
\hline LVDd (mm) & $47.0 \pm 5.2$ & $45.4 \pm 4.3$ & 0.229 \\
\hline LVDs (mm) & $28.1 \pm 4.6$ & $27.2 \pm 5.3$ & 0.496 \\
\hline IVSTd (mm) & $10.0 \pm 2.3$ & $9.8 \pm 2.2$ & 0.770 \\
\hline PWTd (mm) & $9.7 \pm 1.8$ & $10.0 \pm 1.5$ & 0.530 \\
\hline LV mass index $\left(\mathrm{g} \mathrm{m}^{-2}\right)$ & $95.1 \pm 24.6$ & $90.9 \pm 21.6$ & 0.527 \\
\hline $\operatorname{LVEF}(\%)$ & $70.1 \pm 6.2$ & $67.2 \pm 8.5$ & 0.159 \\
\hline$E / A$ & $0.9 \pm 0.2$ & $0.9 \pm 0.3$ & 0.870 \\
\hline DcT (ms) & $220.7 \pm 61.4$ & $192.8 \pm 52.8$ & 0.121 \\
\hline
\end{tabular}

Abbreviations: BNP, brain natriuretic peptide; DcT, deceleration time; HbAlc, hemoglobin Alc; HDL, high-density lipoprotein; HOMA index, homeostasis model assessment index; hs-CRP, high sensitivity-C-reactive protein; IVSTd, interventricular septum thickness in diastole; LDL lowdensity lipoprotein; LVDd, left ventricular internal dimension in diastole; LVDs, left ventricular diameter at end systole; LVEF, left ventricular ejection fraction; PAI-1, plasminogen activator inhibitor-1; PWTd, posterior left ventricular wall thickness in diastole.

Data are expressed as mean \pm s.d.

index at baseline indicated no significant associations between the change of IMT and those factors. There were no significant differences in the changes in cardiac function, LVMI or brain natriuretic peptide between the two groups (Tables 2 and 4).

Over 1 year, there were no significant differences between the two groups with respect to changes in surrogate markers such as serum adiponectin, creatinine, insulin, HOMA index, plasminogen activator inhibitor-1, high sensitivity C-reactive protein and total cholesterol levels (Tables 2 and 4).

\section{DISCUSSION}

TALENT was designed to compare the cardiovascular protective effects of telmisartan and losartan in Japanese patients with mild to moderate hypertension. Throughout the trial, BP levels were well controlled and remained similar in the two groups. The percentage of patients who received monotherapy was significantly higher in the telmisartan group than in the losartan group. The progression of IMT of the common carotid artery was significantly inhibited in the telmisartan group compared with the losartan group. There were no differences in the changes in cardiac function, LVMI or surrogate markers related to the actions of PPAR $\gamma$.

Hypertension is the major risk factor of cardiovascular clinical events such as cardiovascular death, MI, heart failure and stroke, and strict BP controls are required to decrease the risk of cardiovascular events. Because the renin-angiotensin system is involved in the pathophysiology of cardiovascular disease, ACE inhibitors have been widely used as antihypertensive drugs. ACE inhibitors are known to reduce the risk of cardiovascular death, MI, stroke and heart failure. In addition, ACE inhibitors reduce bradykinin degradation, which enhances vasodilatation, but also increase the rates of angioedema and cough. Because ARBs are known to have the same preventive effect on cardiovascular events as ACE inhibitors, they are widely used as first-line antihypertensive drugs.

Telmisartan has been reported to have a partial PPAR $\gamma$ agonist effect, ${ }^{23}$ and reduce glucose, insulin and triglyceride levels in mice fed a high-fat diet. ${ }^{17}$ Telmisartan and irbesartan, unique among the ARBs, significantly increased PPAR $\gamma$ activity in a study using mouse preadipocyte cell cultures, but losartan and eprosartan did not. ${ }^{24}$ Activation of PPAR $\gamma$ suppresses production of inflammatory cytokines, ${ }^{25}$ and there is accumulating evidence that $\operatorname{PPAR} \gamma$ agonists inhibit cardiomyocyte hypertrophy, ${ }^{26}$ inflammation, oxidative stress and proliferation of vascular wall cells. ${ }^{27,28}$ The Prospective Pioglitazone Clinical Trial in Macrovascular Events (PROactive) trial has proven that pioglitazone, one of the PPAR $\gamma$ ligands, inhibits the progression of cardiovascular events. ${ }^{29}$

Recently, assessment of carotid IMT has emerged as a simple and non-invasive technique for measuring atherosclerotic burden. ${ }^{30}$ Unlike serum biomarkers that have been linked to the risk of atherosclerosis, carotid IMT has the theoretical advantage of directly visualizing atherosclerosis in the vessel wall. ${ }^{31}$ Treatment with pioglitazone has previously been reported to decrease the progression of IMT in Japanese type $2 \mathrm{DM}$ patients. ${ }^{32}$ In TALENT, telmisartan treatment significantly inhibited the progression of IMT of common carotid artery compared with losartan. Cross-sectional studies have demonstrated that the age-related increases in common IMT were about $0.010 \mathrm{~mm}$ per year in healthy men and about $0.014 \mathrm{~mm}$ per year in healthy women. Randomized controlled trials have shown that annual progression of IMT in the placebo group varied from $0.013 \mathrm{~mm}$ to $0.120 \mathrm{~mm}$, depending on patients' status with respect to cardiovascular risk factors. ${ }^{33,34}$ In an observational study, IMT progressed annually about $0.020-0.100 \mathrm{~mm}$ per year in hypertensive patients. ${ }^{35}$ In TALENT, the IMT changed $0.200 \mathrm{~mm}$ in the losartan group and $0.010 \mathrm{~mm}$ in the telmisartan group over 1 year. Therefore, we think that the IMT change was significantly smaller in the telmisartan group than in the losartan group. It remains unclear whether telmisartan can lead to a decrease in cardiovascular events, and an additional large trial is expected to compare the effects of telmisartan and other ARBs on the occurrence of major cardiovascular events in Japanese patients with hypertension.

The Framingham Heart Study reported a relationship between an increase in LV mass as determined by echocardiography and cardiovascular events. ${ }^{36}$ Because the percentage of patients with LV hypertrophy was low and the degree of LV hypertrophy was small, telmisartan treatment could not show the significant reduction of LV hypertrophy observed in the present study.

Telmisartan has reportedly also had beneficial effects on the hemodynamic and metabolic impairments in MetS, such as insulin resistance and glucose intolerance. ${ }^{12}$ Randomized controlled studies compared the effect of telmisartan with losartan, and the use of telmisartan resulted in a significant reduction in clinic SBP and DBP when compared with losartan by meta-analysis. ${ }^{37}$ Vitale et al. ${ }^{38}$ investigated the metabolic effects of $80 \mathrm{mg}$ per day telmisartan or $50 \mathrm{mg}$ per day losartan treatment for 3 months in Italian hypertensive MetS patients and found significant decreases in insulin, HOMA index and HbAlc levels in the telmisartan treatment group but not in the 
losartan group. The study demonstrated a significant decrease in 24hour mean BP in both treatment groups, but telmisartan led to larger reductions in SBP and DBP as compared with losartan. These findings might be attributable to the PPAR $\gamma$ activity of telmisartan. In the AMADEO study, telmisartan was superior to losartan in reducing proteinuria in hypertensive patients with diabetic nephropathy despite a similar reduction in $\mathrm{BP} .{ }^{39}$ Masuda et al. ${ }^{40}$ reported that telmisartan reduced proteinuria and improved the ambulatory short-term BP variability in type $2 \mathrm{DM}$ patients compared with losartan. However, Bahadir et al. ${ }^{41}$ reported that telmisartan and losartan had neutral effects on insulin resistance in hypertensive MetS patients. In the present study, we did not detect ameliorating effects of telmisartan on glucose and lipid metabolism and renal function over the 1-year follow-up. Although several investigators have reported that telmisartan significantly improved insulin-resistance markers such as the HOMA index in hypertensive patients with poorly controlled type 2 $\mathrm{DM},{ }^{42}$ we did not identify any superiority of telmisartan over losartan in this regard. In our trial, the HOMA index levels in both groups were not very high and there were few patients with type 2 DM. Because the TALENT participants had mild to moderate hypertension, further studies targeting high-risk patients with DM or MetS are warranted to determine the effects of telmisartan on insulin sensitivity, lipid metabolism and renal function.

To date, many trials have been designed to evaluate the beneficial effects of antihypertensive agents in high-risk hypertensive patients. Although it is important to identify the optimal treatment for highrisk hypertensive patients, it is also necessary to examine the appropriate treatment for low-risk patients with mild to moderate hypertension. TALENT seems to be a unique study in which patients with low-risk hypertension were enrolled. The percentage of patients who could control BP with monotherapy was significantly larger in the telmisartan group than in the losartan group. In addition, treatment with a single pill may be associated with higher adherence to hypertension therapy than a regimen calling for many pills. Metaanalyses have demonstrated that medication compliance declines as the number of daily agents increases. ${ }^{43,44}$ Therefore, telmisartan may be a more useful agent than losartan to control BP in patients with mild to moderate hypertension.

In conclusion, telmisartan treatment significantly reduced the progression of carotid IMT compared with losartan in Japanese hypertensive patients. Telmisartan may have vascular protective effects beyond its antihypertensive property. Additional large trials are needed to examine the effects of telmisartan on cardiovascular events.

\section{CONFLICT OF INTEREST}

The authors declare no conflicts of interest.

\section{ACKNOWLEDGEMENTS}

We thank all the participants, physicians, medical staff and other contributors to TALENT.

1 The Japanese society of hypertension. Guidelines for the management of hypertension 2009. The Japanese society of hypertension: Tokyo, 2009.

2 Cohn JN, Tognoni G. A randomized trial of the angiotensin-receptor blocker valsartan in chronic heart failure. N Engl J Med 2001; 345: 1667-1675.

3 Lindholm LH, Ibsen $\mathrm{H}$, Dahlof B, Devereux RB, Beevers G, de Faire U, Fyhrquist F, Julius S, Kjeldsen SE, Kristiansson K, Lederballe-Pedersen O, Nieminen MS, Omvik P, Oparil S, Wedel H, Aurup P, Edelman J, Snapinn S. Cardiovascular morbidity and mortality in patients with diabetes in the Losartan Intervention For Endpoint reduction in hypertension study (LIFE): a randomised trial against atenolol. Lancet 2002; 359: 1004-1010
4 Pfeffer MA, Swedberg K, Granger CB, Held P, McMurray JJ, Michelson EL, Olofsson B, Ostergren J, Yusuf S, Pocock S. Effects of candesartan on mortality and morbidity in patients with chronic heart failure: the CHARM-Overall programme. Lancet 2003; 362 . 759-766.

5 McMurray JJ, Ostergren J, Swedberg K, Granger CB, Held P, Michelson EL, Olofsson B, Yusuf S, Pfeffer MA. Effects of candesartan in patients with chronic heart failure and reduced left-ventricular systolic function taking angiotensin-converting-enzyme inhibitors: the CHARM-Added trial. Lancet 2003; 362: 767-771.

6 Granger CB, McMurray JJ, Yusuf S, Held P, Michelson EL, Olofsson B, Ostergren J, Pfeffer MA, Swedberg K. Effects of candesartan in patients with chronic heart failure and reduced left-ventricular systolic function intolerant to angiotensin-convertingenzyme inhibitors: the CHARM-Alternative trial. Lancet 2003; 362: 772-776.

7 Yusuf S, Pfeffer MA, Swedberg K, Granger CB, Held P, McMurray JJ, Michelson EL, Olofsson B, Ostergren J. Effects of candesartan in patients with chronic heart failure and preserved left-ventricular ejection fraction: the CHARM-Preserved Trial. Lancet 2003; 362: 777-781

8 Reaven GM. Banting lecture 1988. Role of insulin resistance in human disease. Diabetes 1988; 37: 1595-1607.

9 Haffner SM, Ruilope L, Dahlof B, Abadie E, Kupfer S, Zannad F. Metabolic syndrome, new onset diabetes, and new end points in cardiovascular trials. J Cardiovasc Pharmacol 2006; 47: 469-475.

10 Takeuchi H, Saitoh S, Takagi S, Ohnishi H, Ohhata J, Isobe T, Shimamoto K. Metabolic syndrome and cardiac disease in Japanese men: applicability of the concept of metabolic syndrome defined by the National Cholesterol Education Program-Adult Treatment Panel III to Japanese men-the Tanno and Sobetsu Study. Hypertens Res 2005; 28: 203-208.

11 Reaven G. The metabolic syndrome or the insulin resistance syndrome? Different names, different concepts, and different goals. Endocrinol Metab Clin North Am 2004; 33: 283-303.

12 Tuck ML. Angiotensin-receptor blocking agents and the peroxisome proliferatoractivated receptor-gamma system. Curr Hypertens Rep 2005; 7: 240-243.

13 Barbier O, Torra IP, Duguay Y, Blanquart C, Fruchart JC, Glineur C, Staels B. Pleiotropic actions of peroxisome proliferator-activated receptors in lipid metabolism and atherosclerosis. Arterioscler Thromb Vasc Biol 2002; 22: 717-726.

14 Yki-Jarvinen H. Thiazolidinediones. N Engl J Med 2004; 351: 1106-1118.

15 Derosa G, Cicero AF, Dangelo A, Gaddi A, Ragonesi PD, Piccinni MN, Salvadeo S, Ciccarelli L, Pricolo F, Ghelfi M, Ferrari I, Montagna L, Fogari R. Thiazolidinedione effects on blood pressure in diabetic patients with metabolic syndrome treated with glimepiride. Hypertens Res 2005; 28: 917-924.

16 Benson III AB, Ajani JA, Catalano RB, Engelking C, Kornblau SM, Martenson Jr JA McCallum R, Mitchell EP, O'Dorisio TM, Vokes EE, Wadler S. Recommended guidelines for the treatment of cancer treatment-induced diarrhea. J Clin Oncol 2004; 22: 2918-2926.

17 Benson SC, Pershadsingh $\mathrm{HA}, \mathrm{Ho} \mathrm{Cl}$, Chittiboyina A, Desai P, Pravenec M, Qi N, Wang J, Avery MA, Kurtz TW. Identification of telmisartan as a unique angiotensin II receptor antagonist with selective PPARgamma-modulating activity. Hypertension 2004; 43: 993-1002.

18 Clasen R, Schupp M, Foryst-Ludwig A, Sprang C, Clemenz M, Krikov M, Thone-Reineke $\mathrm{C}$, Unger T, Kintscher U. PPARgamma-activating angiotensin type-1 receptor blockers induce adiponectin. Hypertension 2005; 46: 137-143.

19 Honda A, Matsuura K, Fukushima N, Tsurumi Y, Kasanuki H, Hagiwara N. Telmisartan induces proliferation of human endothelial progenitor cells via PPARgamma-dependent PI3K/Akt pathway. Atherosclerosis 2009; 205: 376-384.

20 Yusuf S, Teo KK, Pogue J, Dyal L, Copland I, Schumacher H, Dagenais G, Sleight P, Anderson C. Telmisartan, ramipril, or both in patients at high risk for vascular events. N Engl J Med 2008; 358: 1547-1559.

21 Palmieri V, Dahlof B, DeQuattro V, Sharpe N, Bella JN, de Simone G, Paranicas M Fishman D, Devereux RB. Reliability of echocardiographic assessment of left ventricular structure and function: the PRESERVE study. Prospective Randomized Study Evaluating Regression of Ventricular Enlargement. J Am Coll Cardiol 1999; 34: 1625-1632.

22 O'Leary DH, Polak JF, Wolfson Jr SK, Bond MG, Bommer W, Sheth S, Psaty BM, Sharrett AR, Manolio TA. Use of sonography to evaluate carotid atherosclerosis in the elderly. The Cardiovascular Health Study. CHS Collaborative Research Group. Stroke 1991; 22: 1155-1163.

23 Pershadsingh HA, Kurtz TW. Insulin-sensitizing effects of telmisartan: implications for treating insulin-resistant hypertension and cardiovascular disease. Diabetes Care 2004; 27: 1015

24 Schupp M, Janke J, Clasen R, Unger T, Kintscher U. Angiotensin type 1 receptor blockers induce peroxisome proliferator-activated receptor-gamma activity. Circulation 2004; 109: 2054-2057.

25 Hasegawa H, Takano H, Zou Y, Qin Y, Hizukuri K, Odaka K, Toyozaki T, Komuro I. Pioglitazone, a peroxisome proliferator-activated receptor gamma activator, ameliorates experimental autoimmune myocarditis by modulating Th1/Th2 balance. $\mathrm{J} \mathrm{Mol} \mathrm{Cell}$ Cardiol 2005; 38: 257-265.

26 Asakawa M, Takano H, Nagai T, Uozumi H, Hasegawa H, Kubota N, Saito T, Masuda Y, Kadowaki T, Komuro I. Peroxisome proliferator-activated receptor gamma plays a critical role in inhibition of cardiac hypertrophy in vitro and in vivo. Circulation 2002; 105: 1240-1246.

27 Hasegawa H, Takano H, Komuro I. Therapeutic Implications of PPARgamma in cardiovascular diseases. PPAR Res 2010; 2010: 876049.

28 Takano H, Komuro I. Peroxisome proliferator-activated receptor gamma and cardiovascular diseases. Circ J 2009; 73: 214-220 
29 Dormandy JA, Charbonnel B, Eckland DJ, Erdmann E, Massi-Benedetti M, Moules IK, Skene AM, Tan MH, Lefebvre PJ, Murray GD, Standl E, Wilcox RG, Wilhelmsen L, Betteridge J, Birkeland K, Golay A, Heine RJ, Koranyi L, Laakso M, Mokan M, Norkus A, Pirags V, Podar T, Scheen A, Scherbaum W, Schernthaner G, Schmitz O, Skrha J, Smith U, Taton J. Secondary prevention of macrovascular events in patients with type 2 diabetes in the PROactive Study (PROspective pioglitAzone Clinical Trial In macroVascular Events): a randomised controlled trial. Lancet 2005; 366: 1279-1289.

30 Kastelein JJ, de Groot E. Ultrasound imaging techniques for the evaluation of cardiovascular therapies. Eur Heart J 2008; 29: 849-858.

31 Duivenvoorden R, de Groot E, Stroes ES, Kastelein JJ. Surrogate markers in clinical trials-challenges and opportunities. Atherosclerosis 2009; 206: 8-16.

32 Koshiyama H, Shimono D, Kuwamura N, Minamikawa J, Nakamura Y. Rapid communication: inhibitory effect of pioglitazone on carotid arterial wall thickness in type 2 diabetes. J Clin Endocrinol Metab 2001; 86: 3452-3456.

33 Costanzo P, Perrone-Filardi P, Vassallo E, Paolillo S, Cesarano P, Brevetti G, Chiariello $M$. Does carotid intima-media thickness regression predict reduction of cardiovascular events? A meta-analysis of 41 randomized trials. J Am Coll Cardiol 2010; 56: 2006-2020.

34 Liviakis L, Pogue B, Paramsothy P, Bourne A, Gill EA. Carotid intima-media thickness for the practicing lipidologist. J Clin Lipidol 2010; 4: 24-35.

35 Shin S, Lee SH, Park S, Kang SM, Chung N, Shim WH, Cho SY, Manabe I, Jang Y. Soluble fms-like tyrosine kinase- 1 and the progression of carotid intima-media thickness-24-month follow-up study. Circ J 2010; 74: 2211-2215.

36 Levy D, Garrison RJ, Savage DD, Kannel WB, Castelli WP. Prognostic implications of echocardiographically determined left ventricular mass in the Framingham Heart Study. N Engl J Med 1990; 322: 1561-1566.

$37 \mathrm{Xi} \mathrm{GL}$, Cheng JW, Lu GC. Meta-analysis of randomized controlled trials comparing telmisartan with losartan in the treatment of patients with hypertension. $A m ~ J$ Hypertens 2008; 21: 546-552.

38 Vitale C, Mercuro G, Castiglioni C, Cornoldi A, Tulli A, Fini M, Volterrani M, Rosano GM. Metabolic effect of telmisartan and losartan in hypertensive patients with metabolic syndrome. Cardiovasc Diabetol 2005; 4: 6.

39 Bakris G, Burgess E, Weir M, Davidai G, Koval S. Telmisartan is more effective than losartan in reducing proteinuria in patients with diabetic nephropathy. Kidney Int 2008; 74: 364-369.
40 Masuda S, Tamura K, Wakui H, Kanaoka T, Ohsawa M, Maeda A, Dejima T, Yanagi M, Azuma K, Umemura S. Effects of angiotensin II type 1 receptor blocker on ambulatory blood pressure variability in hypertensive patients with overt diabetic nephropathy. Hypertens Res 2009; 32: 950-955.

41 Bahadir O, Uzunlulu M, Oguz A, Bahadir MA. Effects of telmisartan and losartan on insulin resistance in hypertensive patients with metabolic syndrome. Hypertens Res 2007; 30: 49-53.

42 Yamana A, Arita M, Furuta M, Shimajiri Y, Sanke T. The angiotensin II receptor blocker telmisartan improves insulin resistance and has beneficial effects in hypertensive patients with type 2 diabetes and poor glycemic control. Diabetes Res Clin Pract 2008; 82: 127-131.

43 Claxton AJ, Cramer J, Pierce C. A systematic review of the associations between dose regimens and medication compliance. Clin Ther 2001; 23: 1296-1310.

44 Laufs U, Rettig-Ewen V, Bohm M. Strategies to improve drug adherence. Eur Heart $J$ 2011 ; 32: 264-268.

\section{APPENDIX}

TALENT investigators:

Shingo Aioi (Chiba Municipal Kaihin Hospital), Yoshiyuki Hama (Chiba Rosai Hospital), Hiroshi Hasegawa (Chiba University Hospital), Eiji Ichimoto (Seirei Sakura Hospital), Yoshihiro Iijima (Chiba Social Insurance Hospital), Takao Namiki (Chiba University Hospital), Tadahiko Mizuguchi (Chiba Social Insurance Hospital), Hiroshi Mizuma (Chiba University Hospital), Hiroya Narumi (Chiba University Hospital), Masashi Ohtsuka (Seirei Yokohama Hospital), Toru Oka (Chiba University Hospital), Hirokazu Shiraishi (Saiseikai Narashino Hospital), Hiroyuki Takano (Chiba University Hospital), Taichi Takizawa (Sanmu Medical Center), Eiji Uchida (Seirei Yokohama Hospital) and Masashi Yamamoto (National Insurance Kimitsu Central Hospital). 